\title{
Sistem Pengendali Pengisian Baterai pada Pembangkit Listrik Tenaga Surya
}

\author{
Asma Ainuddin*1, Salama Manjang ${ }^{1}$, Faizal Arya Samman ${ }^{1}$ \\ ${ }^{1}$ Teknik Elektro, Fakultas Teknik, Universitas Hasanuddin Makassar \\ Jl. Perintis Kemerdekaan Km. 10, Tamalanrea Indah, Makassar, \\ *Email: asmaainuddin11@gmail.com
}

\begin{abstract}
Abstrak
Kerusakan baterai merupakan permasalahan yang sering terjadi pada Pembangkit Listrik Tenaga Surya. Beberapa penyebabnya yaitu keadaan pengisian yang berlebih, tegangan terlampau rendah dan suhu baterai yang terlalu panas. Pemanfaatan sistem kendali pengisian baterai merupakan solusi terbaik. Selain berfungsi untuk mempertahankan tegangan luaran panel surya pada level tegangan baterai, sistem ini juga mengendalikan waktu pengisian. Pada paper ini, sistem pengisian baterai dibangun dari rangkaian DC ke DC konverter menggunakan charge pump, rangkaian kendali menggunakan Arduino Mega, dan rangkaian pengisian baterai. Tahap perancangan terdiri dari simulasi, pembuatan perangkat keras, dan perangkat lunak. Simulasi karakteristik charge pump menggunakan PSpice dengan konfigurasi dioda dan Mosfet sebagai komponen pensaklaran. Karakteristik yang didapatkan berupa penguatan tegangan maksimum sebesar 2.44×, rekuensi kerja $10 \mathrm{kHz}$ hingga $250 \mathrm{kHz}$, dan nilai tahanan beban antara $1 \mathrm{Ohm}$ hingga $5 \mathrm{kOhm}$. Berdasarkan hasil tersebut diketahui pula bahwa penggunaan dioda lebih baik dibanding penggunaan Mosfet, oleh karena itu perangkat keras charge pump dirancang dengan menggunakan dioda. Pengetesan rangkaian dilakukan dengan menghubungkan panel surya ke masukan sistem kendali, hasil akhir menunjukkan sistem kendali pengisian baterai mampu mempertahankan kondisi tegangan pada level baterai yaitu sebesar $12 \mathrm{~V}$ walaupun tegangan panel surya bervariasi pada nilai $6 \mathrm{~V}$ hingga $10 \mathrm{~V}$.
\end{abstract}

\begin{abstract}
The Battery fault is a problem that occurs in Solar Power Plant. It happens because over-charging, undervoltage and over-temperature. Used battery charging control system is the best solution. In addition to maintaining the output voltage of the solar panel at the battery voltage level, this system also controls the charging time. In this paper, the battery charging system is built from DC to DC converter circuit using charge pump, control circuit using Arduino Mega, and battery charging circuit. The design stage consists of simulation, hardware-design, and software-design. Simulation of charge pump characteristics using Pspice with diode configuration and Mosfet as switching component. Characteristics obtained in the form of maximum voltage gain of $2.44 \mathrm{x}$, working frequency of $10 \mathrm{kHz}$ up to $250 \mathrm{kHz}$, and load resistance value between $1 \mathrm{Ohm}$ to $5 \mathrm{kOhm}$. Based on these results, the circuit with diodes is better than Mosfets, therefore the charge pump hardware is designed using diodes. The circuit testing by connecting the solar panel to the control system input, the final result shows that the battery charging control system is able to maintain the voltage condition at the battery level of $12 \mathrm{~V}$ although the solar panel voltage varies from $9 \mathrm{~V}$ to $10 \mathrm{~V}$.
\end{abstract}

Kata-kunci: Energi terbarukan, Konverter DC/DC, Kontroler PID.

\section{Pendahuluan}

Permintaan energi dunia terus meningkat sepanjang sejarah peradaban umat manusia. Proyeksi permintaan energi pada tahun 2050 hampir mencapai tiga kali lipat. Tampaknya masalah energi akan tetap menjadi topik yang harus dicarikan solusinya secara bersama-sama. Pemanfaatan energi telah berkembang dan meningkat sesuai dengan perkembangan manusia itu sendiri. Usaha untuk mendapatkan energi alternatif telah lama dilakukan untuk mengurangi ketergantungan terhadap sumber daya minyak bumi. Pemanfaatan minyak bumi diperkirakan akan habis dalam waktu yang tidak lama jika pola pemakaian seperti sekarang ini yang justru semakin meningkat dengan meningkatnya industri maupun transportasi [1]. Permintaan listrik di Indonesia tumbuh dari 90 terawatt-hours (TWh) di tahun 2003 menjadi 190 TWh di tahun 2013. Namun, jumlah pasokan tidak dapat mengejar laju permintaan yang mengakibatkan terjadinya pemadaman. Solusi saat ini masih bergantung pada bahan bakar minyak dimana kurang lebih 13 persen dari listrik Indonesia masih dihasilkan dari bahan bakar minyak. Biaya untuk menghasilkan listrik dari bahan bakar minyak tidak murah, yaitu dikisaran harga 0,18 sen/kWh dibandingkan dengan 0,05 sen/kWh 
jika menggunakan batu bara. Hanya $1 \mathrm{GW}$ dari potensi geotermal Indonesia yang dikembangkan. Kekurangan sumber daya listrik yang handal dan murah menjadi penghambat bagi pertumbuhan industri dan pembangunan sektor manufaktur di Indonesia untuk terus tumbuh mencapai skala yang sama dengan negara-negara tetangganya [2]. Krisis energi yang terjadi dapat diatasi dengan memanfaatkan potensi energi lain yang terbarukan, misalnya energi surya.

Pemanfaatan pembangkit listrik tenaga surya di Indonesia memiliki potensi yang sangat besar, didukung dengan letak geografis dan iklim yang ada. Indonesia yang berada dalam wilayah khatulistiwa rata-rata setiap harinya mendapatkan intensitas penyinaran selama 10 sampai 12 jam [3].

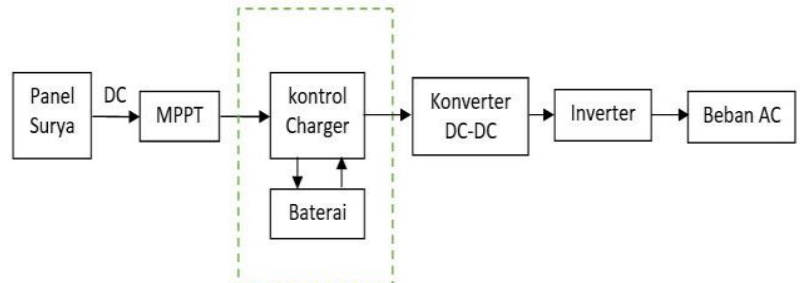

Gambar 1. Bagian-bagian PLTS

Terlihat pada Gambar 1 bagian-bagian pada PLTS diantaranya panel surya, MPPT, kontrol charger, baterai, DC-DC converter, inverter, dan beban AC. Energi surya dikonversi menjadi energi listrik melalui panel surya atau fotovoltaik. Energi listrik yang dihasilkan kemudian disalurkan ke beban dan sebagian disimpan dalam sebuah baterai. Baterai merupakan komponen penting pada pembangkit listrik tenaga surya, yang berfungsi untuk menyimpan energi listrik yang dihasilkan oleh panel surya. Sehingga listrik tetap dapat digunakan pada malam hari. Kontrol charger digunakan sebagai kendali pengisian baterai dan menjaga level teagangan baterai pada kondisi normal. DC-DC converter mampu mengubah nilai keluaran baterai menjadi nilai tertentu sehingga dapat digunakan langsung untuk beban DC. Sedangkan inverter digunakan untuk mengubah tegangan keluaran baterai menjadi tegangan AC agar dapat digunakan oleh beban AC.

Tahun 2011, Shi-cheng Zheng dan Liangyu Wang melakukan penelitian dengan judul Research on Charging Control for Battery in Photovoltaik System. Penelitian ini bertujuan mengatasi masalah rentan hidup baterai yang belum optimal, yang merupakan kendala pada perkembangan industri panel surya. Dalam penelitian ini dilakukan simulasi untuk menganalisa arus, tegangan, dan temperature baterai. Metode pengisian tiga tahap digunakan untuk mempertahankan kondisi baterai dalam sistem ini. Hasil penelitian menunjukkan bahwa proses pengisian membutuhkan waktu yang singkat dan peningkatan tingkat akurasi pengisian pada tegangan konstan dan outcharge sehingga rentan hidup baterai dapat lebih panjang [4].

Tahun 2013, Kevin O. Davis, dkk melakukan penelitian dengan judul Novel Cascaded Batterry Charging Architecture for Photovoltaik System. Dalam karya ini, arsitektur pengisian baterai yang diusulkan dan divalidasi menggunakan energi fotovoltaik optimal untuk melakukan pengisian baterai dengan cepat dan aman. Menggunakan charge controller bertujuan untuk memperpanjang hidup baterai melalui pemantauan karakteristik baterai, dan kemudian menentukan proses pengisian baterai yang tepat, cepat dan esfsien. Penelitian ini dilakukan dengan simulasi, dimana panel surya disusun secara array dengan MPPT menggunakan algoritma Perturb and Observe $(\mathrm{P} \& \mathrm{O})$ untuk mencari daya output maksimum yang terintegrasi dengan sistem pengisian baterai [5].

Tahun 2015, Florin Biziitu melakukan penelitian dengan judul Dickson Charge Pump Regulation Mecanism Optimized for EMC Performance. Pada penelitiannya, ditambahkan kontrol adaptif pada tegangan sumber Dickson charge pump sehingga mampu meningkatkan efisiensi daya [6].

\section{Deskripsi Permasalahan}

Salah satu permasalahan yang sering terjadi pada PLTS yaitu kerusakan baterai. Keadaan over charging, under voltage dan temperatur baterai yang terlalu panas sering menjadi pemicu kerusakan pada baterai. Oleh karena itu dibutuhkan sebuah Sistem Pengendali Pengendali Pengisian Baterai pada PLTS sebagai topik penelitian pada paper ini, sehingga kondisi baterai dapat diketahui secara real time. Dengan sistem kontrol ini, usia penggunaan baterai dapat diperpanjang. 


\section{Perancangan}

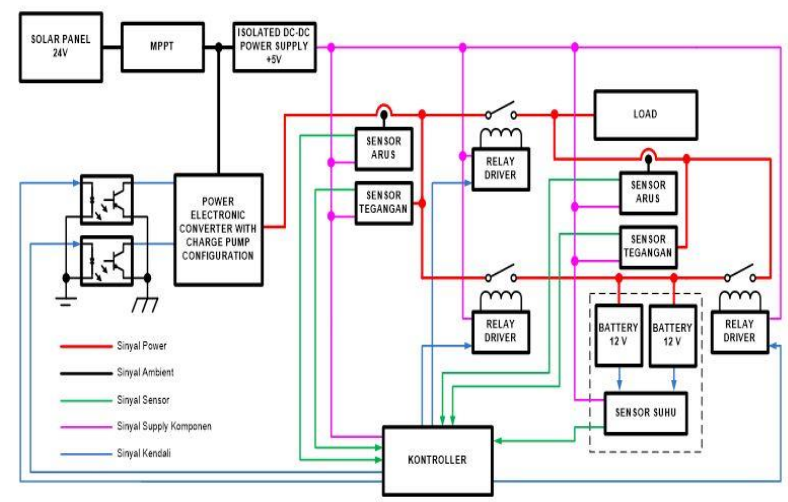

Gambar 2. Blok diagram sistem pengendali kontrol charging baterai

Blok diagram pengisian baterai diperlihatkan pada Gambar 2, sistem menggunakan rangkaian DC ke DC konverter. Tipe konverter yang digunakan yaitu Charge Pump, CP (pompa muatan). CP menggunakan kapasitor sebagai elemen penyimpan energi untuk membuat sumber daya tegangan menjadi tinggi atau rendah. $\mathrm{CP}$ digunakan dalam banyak aplikasi seperti Power IC, CMOS [7], time filters, dan EEPROM, karena tegangan yang lebih tinggi dari catu daya sering dibutuhkan. Rangkaian $\mathrm{CP}$ yang digunakan dalam penelitian yaitu $\mathrm{CP} 2$ tahap dengan dioda.

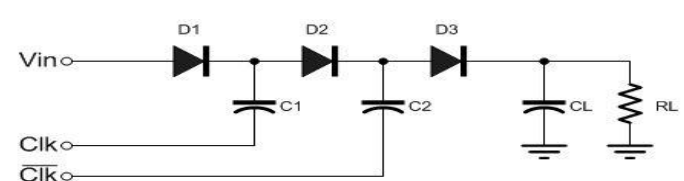

(a)

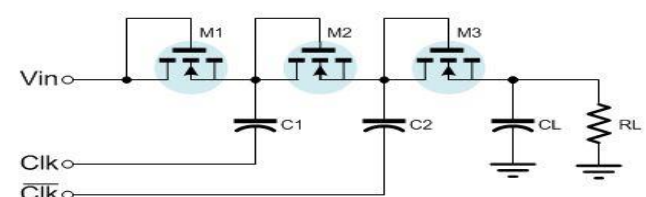

(b)

Gambar 3. Model simulasi CP: (a) dioda; (b) Mosfet

Gambar 3 menunjukkan skema rangkaian dengan mengganti saklar dengan konfigurasi dioda (a) dan Mosfet (b). Keuntungan utama yang diberikan oleh dioda adalah tidak adanya sinyal kontrol saklar. Kelemahannya adalah pengurangan voltase keluaran $\mathrm{CP}$ karena ketika sebuah dioda dibias maju, hal itu menyebabkan kehilangan tegangan sama dengan voltase maju dioda [8]. Sistem yang dirancang menggunakan Arduino Mega sebagai kontroler utama. Arduino beroperasi berdasarkan program yang disematkan di dalam memori mikrokontroler- nya. Perintah yang disematkan termasuk pembacaan sensor tegangan dan pembangkitan pulsa untuk mengatur waktu pensaklaran $\mathrm{CP}$ [9].

\subsection{Pemodelan PSpice}

Pemodelan simulasi $\mathrm{CP}$ dengan dioda terdiri dari tiga skenario yaitu simulasi $\mathrm{CP}$ terhadap tegangan masukan bervariasi dengan tahanan beban dan frekuensi tetap, simulasi CP terhadap frekuensi yang bervariasi dengan tegangan masukan dan tahanan beban yang tetap, dan simulasi CP terhadap tahanan beban bervariasi dengan tegangan masukan dan frekuensi yang tetap.

Model rangkaian $\mathrm{CP}$ menggunakan dioda sebagai komponen pensaklaran pada ditunjukkan pada Gambar 4, sedangkan CP menggunakan Mosfet pada Gambar 5.

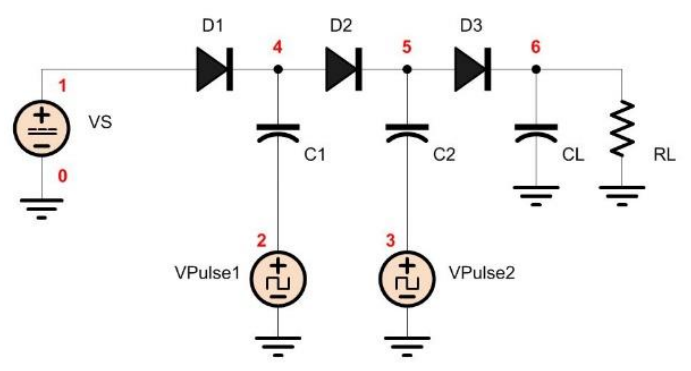

Gambar 4. Model Rangkaian simulasi CP dioda

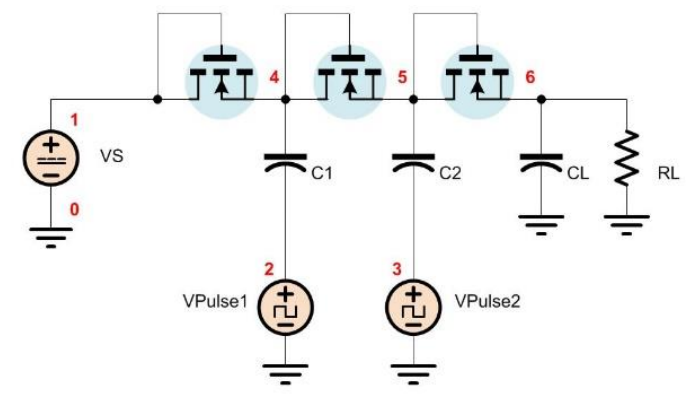

Gambar 5. Model rangkaian simulasi CP Mosfet

\subsection{Skenario Simulasi}

Gambar 6 (a) adalah diagram pengukuran pada simulasi $\mathrm{CP}$ terhadap tegangan masukan bervariasi dengan tahanan beban dan frekuensi tetap. Pengukuran ini bertujuan untuk melihat karakteristik CP terhadap perubahan tegangan masukan. Parameter tegangan masukan akan diatur bervariasi tanpa mengubah tahanan beban RL dan frekuensi pulse. Tegangan masukan maksimum yang diberikan sesuai dengan spesifikasi solar cell yaitu sebesar 36 V. Tegangan minimum yang diberikan yaitu 6 $\mathrm{V}$. 


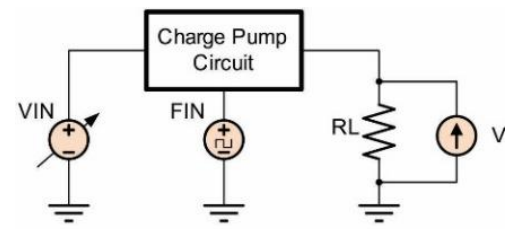

(a)

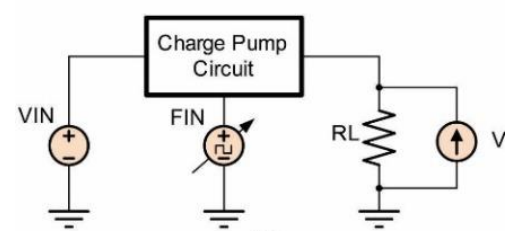

(b)

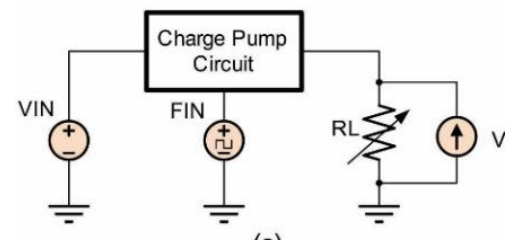

(c)

Gambar 6. Diagram pengukuran tanpa sistem

kendali: (a) Tegangan masukan berubah; (b)

Frekuensi Pulse Berubah; (c) Tahanan beban berubah

Gambar 6 (b) adalah diagram pengukuran pada simulasi CP terhadap frekuensi yang bervariasi dengan tegangan masukan dan tahanan beban yang tetap. Pengukuran ini bertujuan untuk melihat karakteristik $\mathrm{CP}$ terhadap perubahan frekuensi pulse dan mengamati frekuensi maksimum dan minimum yang dapat diberikan pada CP. Parameter frekuensi pulse akan diatur bervariasi tanpa mengubah resistansi beban RL dan tegangan masukan. Frekuensi pulse yang diberikan yaitu sebesar $1 \mathrm{~Hz}$ hingga $260 \mathrm{kHz}$. Tegangan masukan yang diberikan yaitu $12 \mathrm{~V}$ dengan resistor beban $10 \mathrm{Ohm}$.

Gambar 6 (c) adalah diagram pengukuran simulasi CP terhadap tahanan beban bervariasi dengan tegangan masukan dan frekuensi yang tetap. Pengukuran ini bertujuan untuk melihat karakteristik CP terhadap perubahan tahanan beban dan mengamati nilai tahanan maksimum dan minimum yang dapat diberikan pada CP. Parameter tahanan akan diatur bervariasi tanpa mengubah frekuensi pulse dan tegangan masukan. Tahanan beban yang diberikan yaitu sebesar $1 \mathrm{Ohm}$ hingga $20 \mathrm{k} \Omega$. Tegangan masukan yang diberikan yaitu $12 \mathrm{~V}$ dengan frekuensi pulse sebesar $100 \mathrm{kHz}$.

\subsection{Perangkat keras}

Gambar 7 memperlihatkan blok dari sistem kendali pengisian baterai yang dibuat. Fungsi dari masing-masing blok yaitu :
- Photo coupler. Blok ini berfungsi untuk memisahkan jalur tegangan power dan kontrol. Terdiri dari komponen photo coupler sebagai pemisah dan resistor sebagai pembatas arus dan pull up.

- Relay driver. Blok ini berfungsi sebagai penggerak relay. Menggunakan transistor sebagai saklar elektronik dan resistor pembatas arus. Kerja dari relay tergantung dari sinyal yang di umpankan pada basis transistor.

- Gate Driver. Blok ini merupakan penggerak Power Mosfet. Terdiri dari transistor dan resistor. Masukan sinyal didapat dari Photo coupler, luaran dari blok ini terhubung dengan gate Power Mosfet.

- Power Mosfet. Merupakan rangkaian daya yang berfungsi menguatkan sinyal pulsa yang akan umpankan ke blok 2 stage charge pump.

- 2 stage charge pump. Bagian ini merupakan rangkaian DC-DC konverter. Rangkaian ini menggunakan dioda sebagai komponen pensaklaran dan kapasitor yang berfungsi sebagai kapasitor transfer dan kapasitor beban.

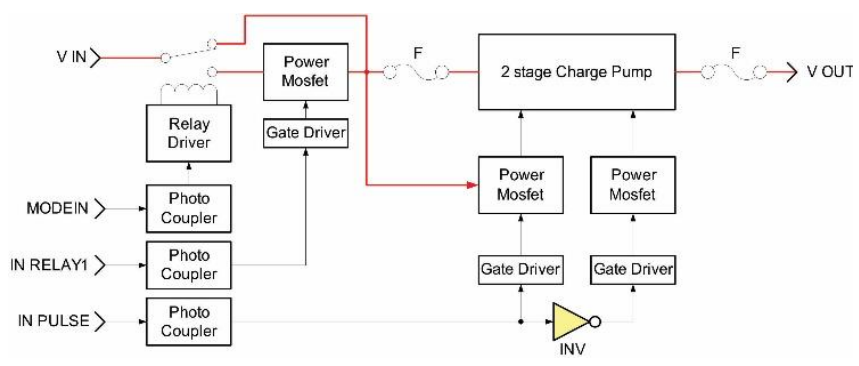

Gambar 7. Diagram blok perancangan sistem kendali pengisian baterai

Gambar 8 menunjukkan diagram alir dari sistem kendali yang dibuat. Kendali yang digunakan merupakan sistem kendali sederhana yang disematkan pada rangkaian kontrol Arduino Mega Sistem akan membandingkan nilai pembacaan keluaran dengan nominal keluaran yang telah ditetapkan.

Jika nilai luaran lebih besar dari nilai yang ditetapkan, maka sistem akan memberikan isyarat pada ragkaian $\mathrm{CP}$ untuk mengurangi penguatan. Sedangkan saat nilai luaran kurang dari nilai yang ditetapkan, maka sistem kendali 
akan memberikan isyarat untuk menambah penguatan pada $\mathrm{CP}$.
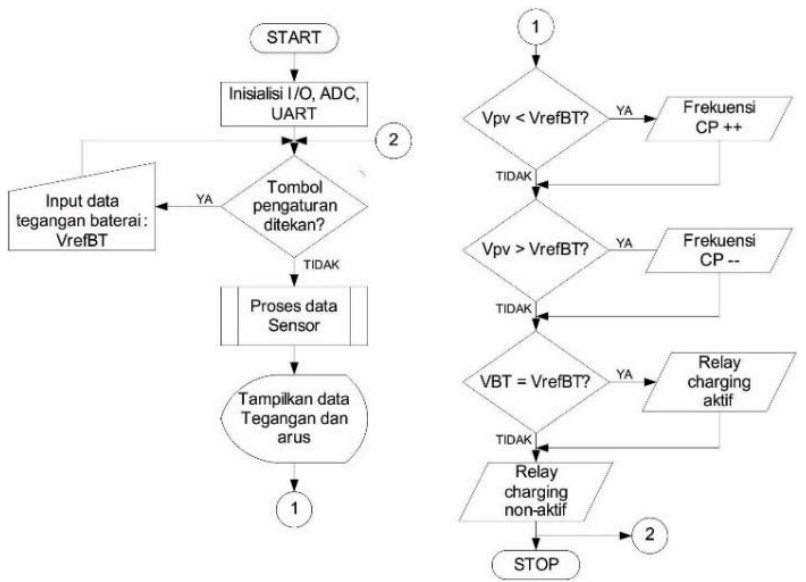

Gambar 8. Diagram alir sistem kendali

\section{Hasil Simulasi dan Perancangan}

4.1. CP Dioda variasi tegangan masukan

Berdasarkan Gambar 9 dan Tabel 1, hubungan antara tegangan luaran dan masukan $\mathrm{CP}$ saat tegangan masukan berubah yaitu nilai tegangan luaran berbanding lurus dengan tegangan masukan. Semakin besar nilai masukan, maka nilai luaran akan semakin besar. Penguatan tengangan yang terjadi yaitu sekitar $2.20 \times$ hingga $2.44 \times$.

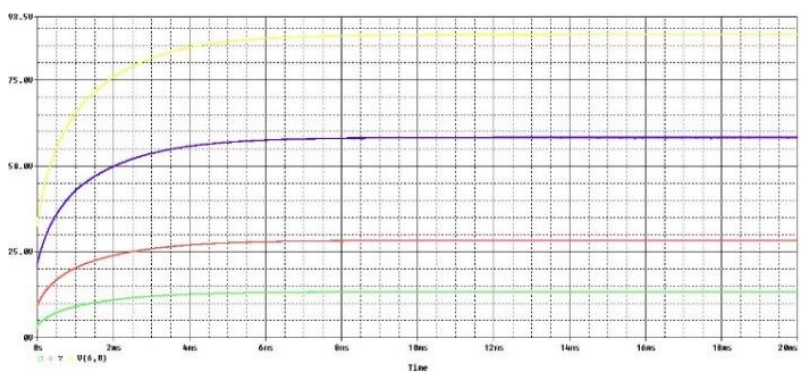

Gambar 9. Hasil Simulasi CP Dioda dengan variasi tegangan masukan

Tabel 1. Nilai tegangan CP Dioda dengan variasi tegangan masukan

\begin{tabular}{ccc}
\hline $\begin{array}{c}\text { Tegangan } \\
\text { Masukan }\end{array}$ & $\begin{array}{c}\text { Tegangan } \\
\text { Luaran }\end{array}$ & $\begin{array}{c}\text { Penguatan } \\
\text { Tegangan }\end{array}$ \\
\hline $6 \mathrm{~V}$ & $13.213 \mathrm{~V}$ & $2.20 \times$ \\
\hline $12 \mathrm{~V}$ & $28.201 \mathrm{~V}$ & $2.35 \times$ \\
\hline $24 \mathrm{~V}$ & $58.176 \mathrm{~V}$ & $2.42 \times$ \\
\hline $36 \mathrm{~V}$ & $88.152 \mathrm{~V}$ & $2.44 \times$ \\
\hline
\end{tabular}

4.2. CP Dioda variasi frekuensi pulse

Berdasarkan Gambar 10 dan Tabel 2, penguatan tegangan akan naik pada frekuensi $10 \mathrm{kHz}$ dengan nilai penguatan sebesar $1.18 \times$. Nilai maksimum penguatan yang dapat dicapai yaitu $2.59 \times$ pada frekuensi $250 \mathrm{kHz}$, frekuensi yang lebih dari $250 \mathrm{kHz}$ akan mengakibatkan penguatan turun. Sehingga frekuensi yang dapat diberikan pada pulse CP yaitu antara 10 $\mathrm{kHz}$ hingga $250 \mathrm{kHz}$.

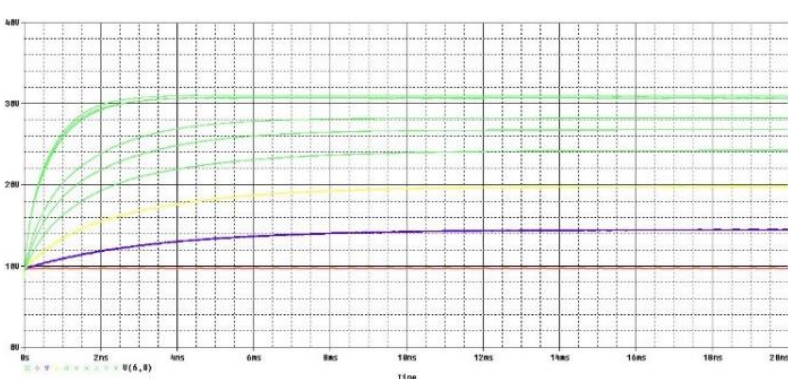

Gambar 10. Hasil Simulasi CP Dioda dengan variasi frekuensi pulse

Tabel 2. Nilai tegangan CP Dioda dengan variasi frekuensi pulse

\begin{tabular}{ccc}
\hline $\begin{array}{c}\text { Frekuensi } \\
\text { Pulse }\end{array}$ & $\begin{array}{c}\text { Tegangan } \\
\text { Luaran }\end{array}$ & $\begin{array}{c}\text { Penguatan } \\
\text { Tegangan }\end{array}$ \\
\hline $1 \mathrm{~Hz}$ & $9.653 \mathrm{~V}$ & $0.80 \times$ \\
\hline $1 \mathrm{kHz}$ & $9.755 \mathrm{~V}$ & $0.81 \times$ \\
\hline $10 \mathrm{kHz}$ & $14.192 \mathrm{~V}$ & $1.18 \times$ \\
\hline $25 \mathrm{kHz}$ & $19.495 \mathrm{~V}$ & $1.62 \times$ \\
\hline $50 \mathrm{kHz}$ & $23.964 \mathrm{~V}$ & $1.99 \times$ \\
\hline $75 \mathrm{kHz}$ & $26.644 \mathrm{~V}$ & $2.22 \times$ \\
\hline $100 \mathrm{kHz}$ & $28.201 \mathrm{~V}$ & $2.35 \times$ \\
\hline $250 \mathrm{kHz}$ & $31.026 \mathrm{~V}$ & $2.59 \times$ \\
\hline $255 \mathrm{kHz}$ & $30.670 \mathrm{~V}$ & $2.56 \times$ \\
\hline $260 \mathrm{kHz}$ & $30.776 \mathrm{~V}$ & $3.56 \times$ \\
\hline
\end{tabular}

Hubungan antara frekuensi pulse dan penguatan tegangan yaitu semakin besar frekuensi pulse, maka penguatan tegangan akan semakin besar. Semakin kecil frekuensi pulse, maka penguatan tegangan akan semakin kecil.

\subsection{CP Dioda variasi tahanan beban}

Berdasarkan Gambar 11 dan Tabel 3, nilai maksimum penguatan yang dapat dicapai yaitu $2.810 \times$ pada tahanan beban $5 \mathrm{k} \Omega$. Penguatan tegangan akan turun mencapai nilai $1.194 \times$ saat tahanan beban $1 \Omega$. Sehingga hubungan antara tahanan beban dan penguatan tegangan yaitu semakin besar tahanan beban, maka penguatan tegangan akan semakin besar. Semakin kecil tahanan beban, maka penguatan tegangan akan semakin kecil.

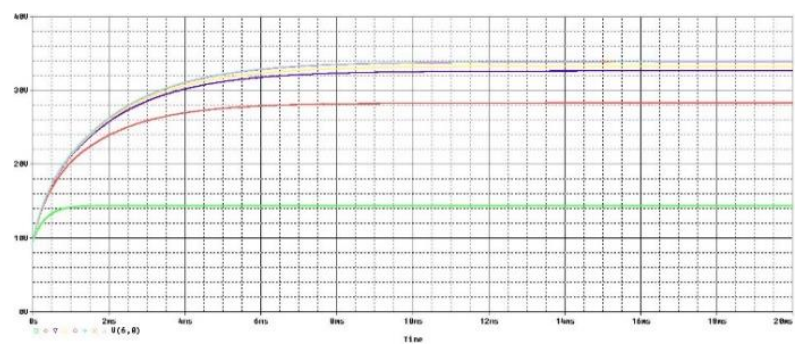

Gambar 11. Hasil Simulasi CP Dioda dengan variasi tahanan beban 
Tabel 3. Nilai tegangan CP Dioda dengan variasi tahanan beban

\begin{tabular}{ccc}
\hline Tahanan & $\begin{array}{c}\text { Tegangan } \\
\text { Luaran }\end{array}$ & $\begin{array}{c}\text { Penguatan } \\
\text { Tegangan }\end{array}$ \\
\hline $1 \Omega$ & $14.328 \mathrm{~V}$ & 1.194 \\
\hline $10 \Omega$ & $28.190 \mathrm{~V}$ & 2.349 \\
\hline $50 \Omega$ & $32.462 \mathrm{~V}$ & 2.705 \\
\hline $100 \Omega$ & $33.085 \mathrm{~V}$ & 2.757 \\
\hline $1 \mathrm{k} \Omega$ & $33.666 \mathrm{~V}$ & 2.806 \\
\hline $5 \mathrm{k} \Omega$ & $33.718 \mathrm{~V}$ & 2.810 \\
\hline $10 \mathrm{k} \Omega$ & $33.725 \mathrm{~V}$ & 2.810 \\
\hline $20 \mathrm{k} \Omega$ & $33.728 \mathrm{~V}$ & 2.810 \\
\hline
\end{tabular}

4.4. CP Mosfet variasi tegangan masukan

Berdasarkan Gambar 12 dan Tabel 4, hubungan antara tegangan luaran dan masukan $\mathrm{CP}$ saat tegangan masukan berubah yaitu nilai tegangan luaran berbanding lurus dengan tegangan masukan. Semakin besar nilai masukan, maka nilai luaran akan semakin besar. Penguatan tengangan yang terjadi yaitu sekitar $2.01 \times$ hingga $1.88 \times$.

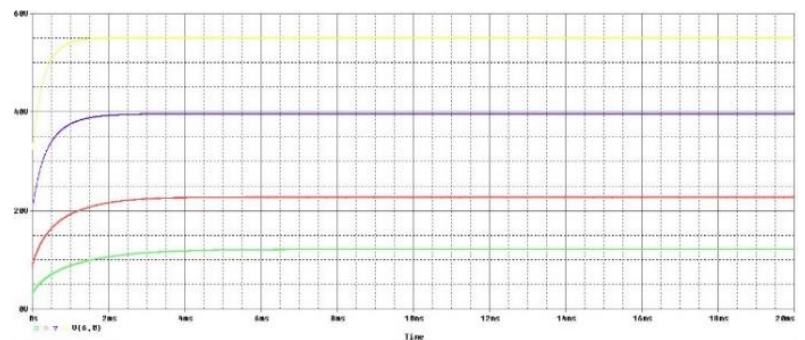

Gambar 12. Hasil Simulasi CP Mosfet dengan variasi tegangan masukan

Tabel 4. Nilai tegangan CP Mosfet dengan variasi tegangan masukan

\begin{tabular}{ccc}
\hline $\begin{array}{c}\text { Tegangan } \\
\text { Masukan }\end{array}$ & $\begin{array}{c}\text { Tegangan } \\
\text { Luaran }\end{array}$ & $\begin{array}{c}\text { Penguatan } \\
\text { Tegangan }\end{array}$ \\
\hline $6 \mathrm{~V}$ & $12.082 \mathrm{~V}$ & $2.01 \times$ \\
\hline $12 \mathrm{~V}$ & $22.619 \mathrm{~V}$ & $1.88 \times$ \\
\hline $24 \mathrm{~V}$ & $39.555 \mathrm{~V}$ & $1.65 \times$ \\
\hline $36 \mathrm{~V}$ & $54.950 \mathrm{~V}$ & $1.53 \times$ \\
\hline
\end{tabular}

\subsection{CP Mosfet variasi frekuensi pulse}

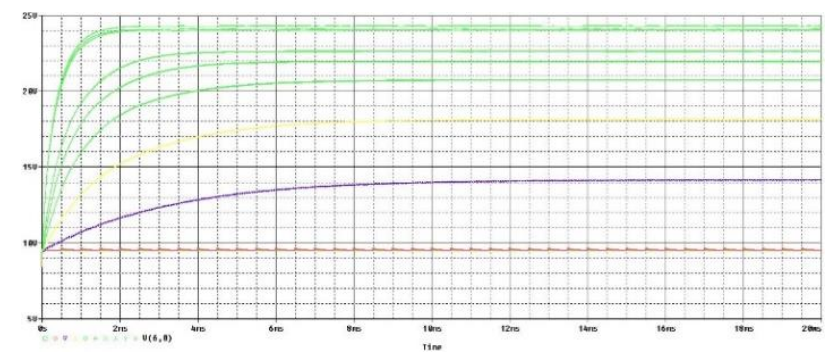

Gambar 13. Hasil Simulasi CP Mosfet dengan variasi frekuensi pulse
Tabel 5. Nilai tegangan CP Mosfet dengan variasi frekuensi pulse

\begin{tabular}{ccc}
\hline $\begin{array}{c}\text { Frekuensi } \\
\text { Pulse }\end{array}$ & $\begin{array}{c}\text { Tegangan } \\
\text { Luaran }\end{array}$ & $\begin{array}{c}\text { Penguatan } \\
\text { Tegangan }\end{array}$ \\
\hline $1 \mathrm{~Hz}$ & $9.503 \mathrm{~V}$ & $0.79 \times$ \\
\hline $1 \mathrm{kHz}$ & $9.503 \mathrm{~V}$ & $0.79 \times$ \\
\hline $10 \mathrm{kHz}$ & $13.963 \mathrm{~V}$ & $1.16 \times$ \\
\hline $25 \mathrm{kHz}$ & $18.089 \mathrm{~V}$ & $1.51 \times$ \\
\hline $50 \mathrm{kHz}$ & $20.739 \mathrm{~V}$ & $1.73 \times$ \\
\hline $75 \mathrm{kHz}$ & $21.973 \mathrm{~V}$ & $1.83 \times$ \\
\hline $100 \mathrm{kHz}$ & $22.647 \mathrm{~V}$ & $1.89 \times$ \\
\hline $250 \mathrm{kHz}$ & $24.310 \mathrm{~V}$ & $2.03 \times$ \\
\hline $255 \mathrm{kHz}$ & $24.107 \mathrm{~V}$ & $2.01 \times$ \\
\hline $260 \mathrm{kHz}$ & $24.060 \mathrm{~V}$ & $2.01 \times$ \\
\hline
\end{tabular}

Berdasarkan Gambar 13 dan Tabel 5, penguatan tegangan akan naik pada frekuensi $10 \mathrm{kHz}$ dengan nilai penguatan sebesar 1.16×. Nilai maksimum penguatan yang dapat dicapai yaitu $2.03 \times$ pada frekuensi $250 \mathrm{kHz}$, frekuensi yang lebih dari $250 \mathrm{kHz}$ akan mengakibatkan penguatan turun. Sehingga frekuensi yang dapat diberikan pada pulse CP yaitu antara 10 $\mathrm{kHz}$ hingga $250 \mathrm{kHz}$. Hubungan antara frekuensi pulse dan penguatan tegangan yaitu semakin besar frekuensi pulse, maka penguatan tegangan akan semakin besar. Semakin kecil frekuensi pulse, maka penguatan tegangan akan semakin kecil.

\subsection{CP Mosfet variasi tahanan beban}

Berdasarkan Gambar 14 dan Tabel 6, nilai maksimum penguatan yang dapat dicapai yaitu $2.041 \times$ pada tahanan beban $5 \mathrm{k} \Omega$. Penguatan tegangan akan turun mencapai nilai $1.142 \times$ saat tahanan beban $1 \Omega$. Sehingga hubungan antara tahanan beban dan penguatan tegangan yaitu semakin besar tahanan beban, maka penguatan tegangan akan semakin besar. Semakin kecil tahanan beban, maka penguatan tegangan akan semakin kecil.

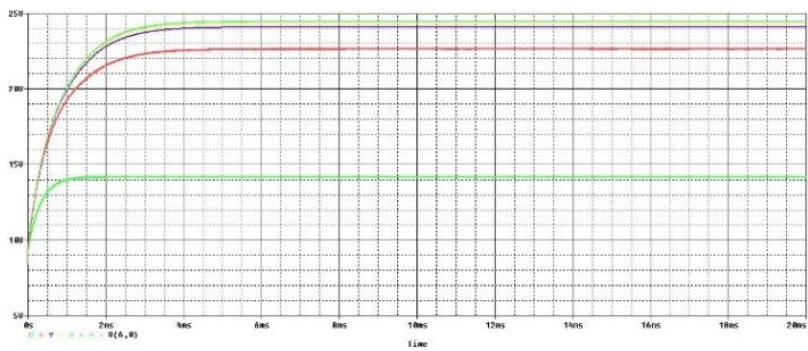

Gambar 14. Hasil Simulasi CP Mosfet dengan variasi tahanan beban 
Tabel 6. Nilai tegangan CP Mosfet dengan variasi tahanan beban

\begin{tabular}{ccc}
\hline Tahanan & $\begin{array}{c}\text { Tegangan } \\
\text { Luaran }\end{array}$ & $\begin{array}{c}\text { Penguatan } \\
\text { Tegangan }\end{array}$ \\
\hline $1 \Omega$ & $14.142 \mathrm{~V}$ & $1.142 \times$ \\
\hline $10 \Omega$ & $22.647 \mathrm{~V}$ & $1.887 \times$ \\
\hline $50 \Omega$ & $24.134 \mathrm{~V}$ & $2.011 \times$ \\
\hline $100 \Omega$ & $24.320 \mathrm{~V}$ & $2.026 \times$ \\
\hline $1 \mathrm{k} \Omega$ & $24.488 \mathrm{~V}$ & $2.040 \times$ \\
\hline $5 \mathrm{k} \Omega$ & $24.503 \mathrm{~V}$ & $2.041 \times$ \\
\hline $10 \mathrm{k} \Omega$ & $24.504 \mathrm{~V}$ & $2.041 \times$ \\
\hline $20 \mathrm{k} \Omega$ & $24.506 \mathrm{~V}$ & $2.041 \times$ \\
\hline
\end{tabular}

4.7. Perbandingan CP Dioda dan Mosfet

Gambar 15 memperlihatkan karakteristik penguatan tegangan terhadap tegangan masukan yang berubah antara CP Dioda dan Mosfet. CP Dioda memiliki penguatan tegangan yang naik seiring dengan naiknya tegangan masukan, sedangkan penguatan tegangan pada CP Mosfet akan menurun seiring dengan bertambahnya tegangan masukan.

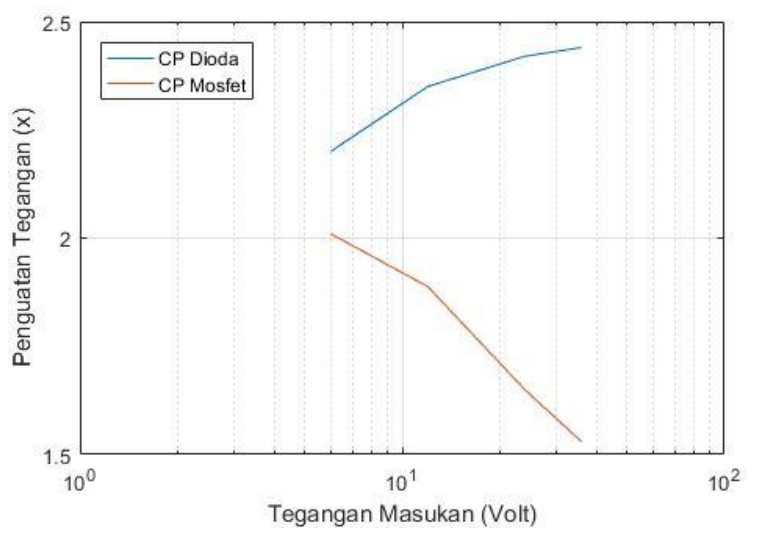

Gambar 15. Grafik perbandingan karakteristik CP Dioda dan CP Mosfet terhadap perubahan nilai Tegangan masukan

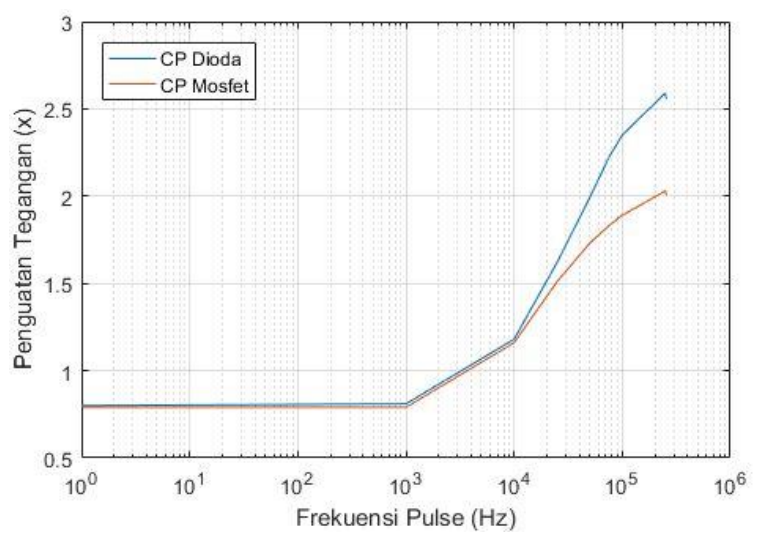

Gambar 16. Grafik perbandingan karakteristik CP Dioda dan CP Mosfet terhadap perubahan nilai Frekuensi Pulse

Gambar 16 memperlihatkan karakteristik penguatan tegangan terhadap frekuensi pulse yang berubah antara CP Dioda dan Mosfet. CP
Dioda dan CP Mosfet keduanya memiliki penguatan tegangan yang naik seiring dengan naiknya frekuensi pulse, tetapi nilai penguatan tegangan $\mathrm{CP}$ dioda lebih besar dibandingkan penguatan tegangan pada CP Mosfet pada frekuensi pulse yang sama. Rentang frekuensi pulse yang memberikan penguatan tegangan pada CP Dioda dan CP Mosfet relatif sama yaitu antara $10 \mathrm{kHz}$ hingga $255 \mathrm{kHz}$.

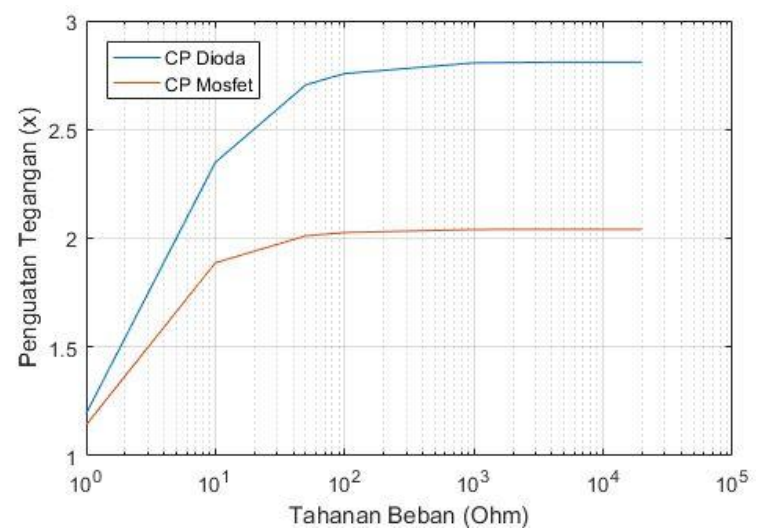

Gambar 17. Grafik perbandingan karakteristik CP Dioda dan CP Mosfet terhadap perubahan nilai tahanan beban

Gambar 17 memperlihatkan karakteristik penguatan tegangan terhadap nilai tahanan beban yang berubah antara CP Dioda dan Mosfet. CP Dioda dan CP Mosfet keduanya memiliki penguatan tegangan yang naik seiring dengan naiknya nilai tahanan beban, tetapi nilai penguatan tegangan $\mathrm{CP}$ diode lebih besar dibandingkan penguatan tegangan pada $\mathrm{CP}$ Mosfet pada nilai tahanan yang sama.

\subsection{Hasil Perancangan}

Gambar 18 menunjukkan hasil rancangan perangkat keras. Terdapat display LCD untuk menampilkan pembacaan tegangan dan arus rangkaian serta tombol untuk melakukan konfigurasi.

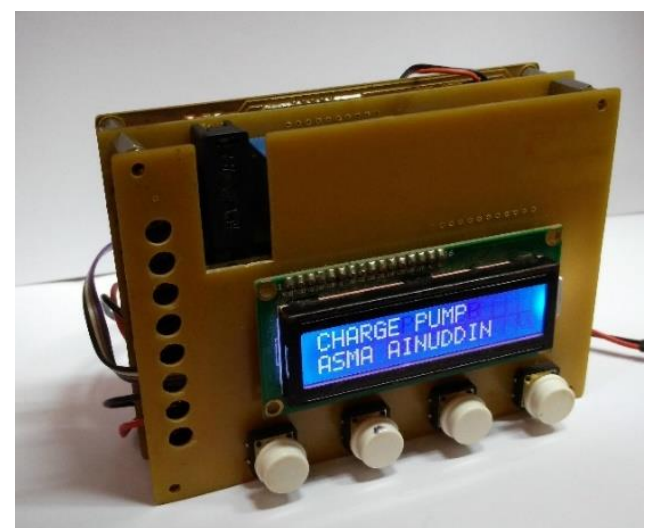

Gambar 18. Hasil Perancangan perangkat keras sistem kendali pengisian baterai 


\subsection{Pengujian perangkat keras}

Pengujian perangkat keras meliputi pengujian karakteristik $\mathrm{CP}$ dan pengujian sistem kendali yang ditampilkan pada antarmuka komputer.

Gambar 19 merupakan grafik perubahan tegangan masukan terhadap penguatan tegangan pada nilai tahanan beban yang berbeda. Nilai tahanan yang diberikan yaitu $100 \Omega \mathrm{v}$ dan Frekuensi pulse $1 \mathrm{kHz}$. Terlihat penguatan tegangan terkecil diperoleh pada nilai tahanan beban $100 \Omega$, dan terbesar pada nilai tahanan beban $4.7 \mathrm{k} \Omega$. Nilai penguatan tegangan cenderung naik seiring bertambahnya nilai tegangan masukan, hanya pada beberapa nilai tegangan masukan yang besar mengakibatkan penguatan turun yang mengakibatkan grafik tidak linear seperti terlihat pada kurva $\mathrm{RL}=100 \Omega$.

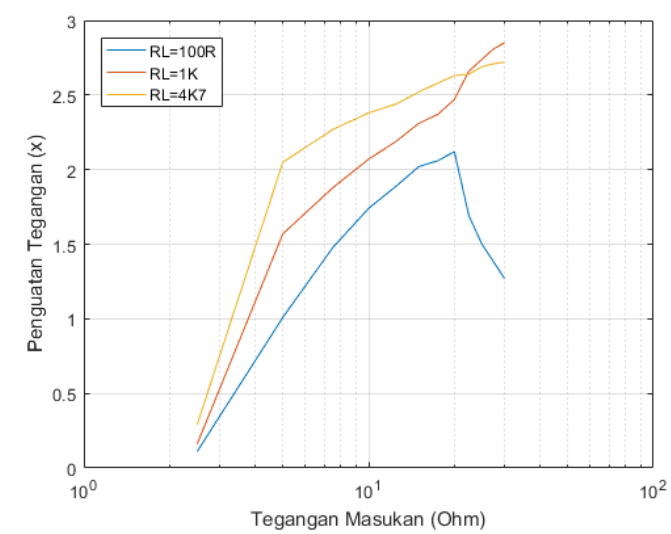

Gambar 19. Grafik perubahan tegangan masukan terhadap penguatan tegangan pada beberapa nilai tahanan beban

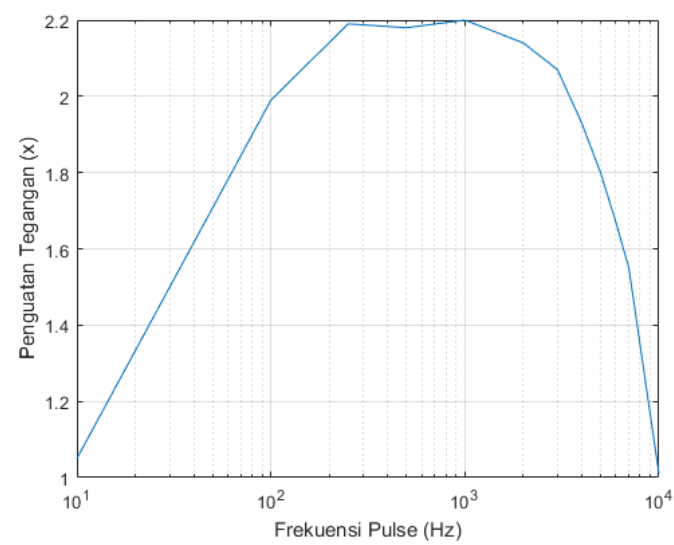

Gambar 20. Grafik perubahan perubahan frekuensi pulse terhadap penguatan tegangan

Gambar 20 merupakan grafik perubahan frekuensi pulse terdahap penguatan tegangan yang menunjukkan nilai penguatan terbesar didapatkan pada frekuensi pulse sebesar $1 \mathrm{kHz}$ yakni sebesar $2.2 \times$. Tegangan masukan yang diberikan sebesar $12 \mathrm{~V}$ dan tahanan beban sebesar $1 \mathrm{k} \Omega$.

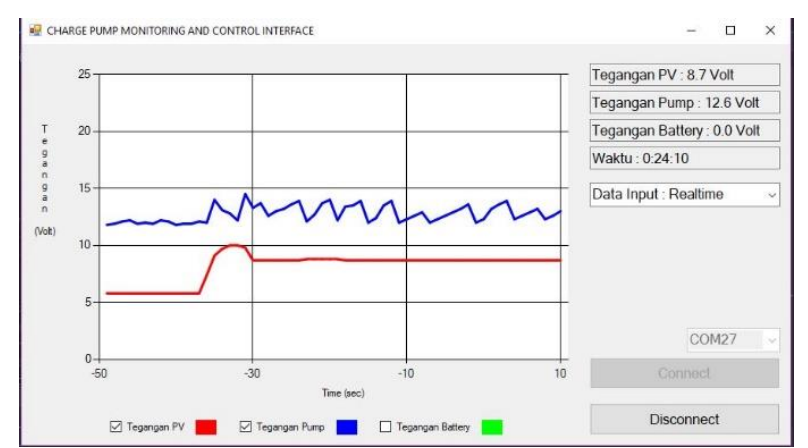

Gambar 21. Tampilan pengujian interface pada level 5V ke 10V

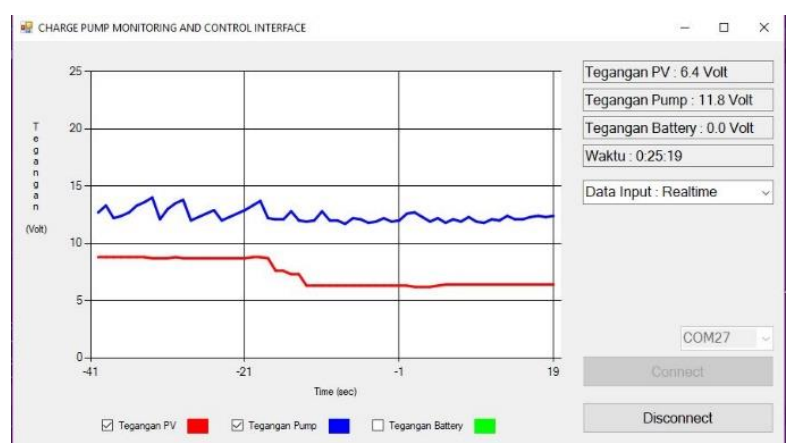

Gambar 22. Tampilan hasil pengujian interface pada level 9V ke 6V

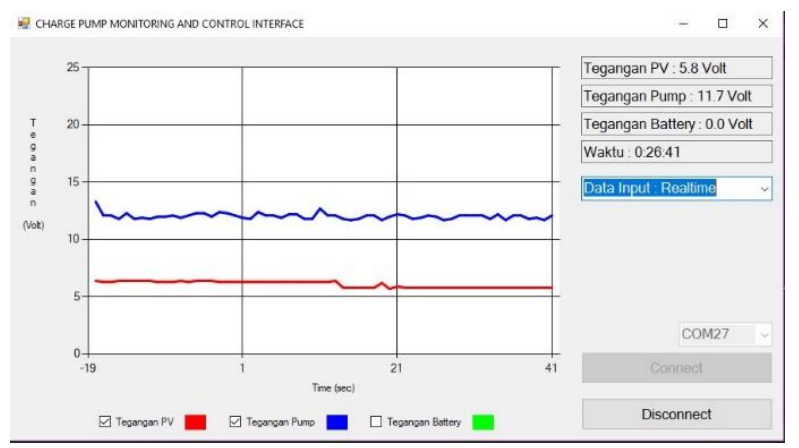

Gambar 23. Tampilan hasil pengujian interface pada level $6 \mathrm{~V}$

Dari keseluruhan pengujian rangkaian menggunakan sistem kendali, diperoleh hasil yaitu rangkaian mampu mempertahankan konsisi luaran pada level tegangan yang telah diatur. Riak akan terjadi saat tegangan masukan berada pada kondisi peralihan dan saat tegangan stabil.

Gambar 21 menunjukkan grafik pada interface saat tegangan masukan beralih dari 5 $\mathrm{V}$ ke $10 \mathrm{~V}$. Pada peralihan ini terjadi riak pada tegangan luaran CP yang mencapai $14 \mathrm{~V}$.

Gambar 22 menunjukkan grafik pada interface saat tegangan masukan beralih dari 9 $\mathrm{V}$ ke $6 \mathrm{~V}$. Pada peralihan ini terjadi riak pada tegangan luaran $\mathrm{CP}$ yang mencapai $14 \mathrm{~V}$. 
Gambar 23 menunjukkan grafik pada interface saat tegangan masukan stabil pada level 6 V. Pada kondisi ini terjadi riak pada tegangan luaran CP yang mencapai $12.8 \mathrm{~V}$.

\section{Kesimpulan}

Peningkatan tegangan masukan pada $\mathrm{CP}$ akan mengakibatkan peningkatan tegangan luaran. Dari simulasi yang dilakukan terhadap CP dengan konfigurasi Dioda dan Mosfet didapatkan hasil bahwa konfigurasi dioda memiliki karakteristik yang lebih baik dari pada konfigurasi Mosfet. Hal ini ditunjukkan oleh penguatan tegangan pada konfigurasi Dioda yang lebih besar dibanding konfigurasi Mosfet pada keadaan yang sama.

Nilai frekuensi kerja pada rangkaian $\mathrm{CP}$ yaitu $10 \mathrm{KHz}$ hingga maksimum $250 \mathrm{kHz}$ dengan nilai penguatan tegangan yang mencapai $2.59 \times$. Karakteristik yang didapatkan menunjukkan peningkatan frekuensi pulse mengakibatkan peningkatan penguatan tegangan.

Pada karakteristik terhadap perubahan tegangan masukan menunjukkan bahwa penguatan tegangan berbanding lurus dengan nilai tegangan masukan. Pengujian rangkaian CP menghasilkan frekuensi kerja yaitu pada frekuensi $1 \mathrm{kHz}$ dengan nilai penguatan tegangan yaitu $2.2 \times$. Pengaruh perubahan frekuensi pulse pada rangkaian $\mathrm{CP}$ menunjukkan hubungan yang tidak linear.

Hasil pengujian sistem menunjukkan bahwa sistem yang dibuat berhasil dan dapat digunakan pada sistem pengisian baterai pada PLTS karena hasil sistem mampu mempertahakan tegangan luaran pada level yang telah diatur yaitu $12 \mathrm{~V}$ dengan variasi tegangan masukan $6 \mathrm{~V}$ hingga $10 \mathrm{~V}$.

\section{Referensi}

[1] J. A. Widodo, Suryono, A. Tatyantoro, and Tugino, "Pemberdayaan Energi Matahari sebagai Energi Listrik Lampu Pengatur Lalu Lintas", UNNES Journals, vol. 8, no. 2, pp. 67-72, 2010.

[2] D. Septiadi, "Proyeksi Potensi Energi Surya Sebagai Energi Terbarukan (Studi Wilayah Ambon dan Sekitarnya)", Jurnal Meteorology dan Geofisika, vol. 10, no. 1, pp. 22-28, 2009.

[3] A. Budiman, K. Das, A. Mohammad, K. T. Tan, and O. Tonby, "Sepuluh gagasan untuk menguatkan kembali sektor energi Indonesia", McKinsey\&Company, 2014.

[4] Qiufeng, W., Yong, X., and Xiangwen, Z. (2011). Research on charging control for battery in photovoltaic system, IEEE Conference on Industrial Electronics and Applications, hal. 2321 - 2325.

[5] Davis, K. O., Ishihara, A. K., Poolla, C., and Arai, S. (2013). Novel cascaded battery charging architecture for photovoltaic systems, Conference Record of the Ieee Photovoltaic Specialists Conference. IEEE 39th Photovoltaic Specialists Conference (PVSC), hal. $1506-1508$.

[6] Florin Biziitu (2015), Dickson Charge Pump Regulation Mecanism Optimized for EMC Performance, International Semiconductor Conference (CAS), hal. 193-196.

[7] Zucchelli, M., Colalongo, L., Richelli, A., and Kovacs-Vajna, Z. M. (2016). A DCDC Charge Pump Design Based on Voltage Doublers. IET Power Electronics, IET Journals \& Magazines, 9:553 - 558.

[8] Palumbo, G. and Pappalardo, D. (2010). Charge pump circuits: An overview on design strategies and topologies. IEEE Circuits and Systems Magazine, 10:31 - 45 .

[9] W. Makni, N. Ben Hadj, H. Samet, R. Neji. (2016). Design simulation and realization of solar battery charge controller using arduino uno. International Conference on Sciences and Techniques of Automatic Control and Computer Engineering (STA), hal. 635 639. 